日本語能力武湌「聴解」間题は現实の日本語使用場面をどの程度反映しているか： テクストの的分析を通して

\title{
谷踝司 北量門大学（韓国）
}

\section{Summary}

The aim of this study was to find out how much listening sections in Japanese Language Proficiency Test (JLPT) reflect real Japanese language use context. For this purpose. this study set up 5 analysis points; 1)setting、2)role、3)function、4)topic, 5)text type and analyzed the listening sections of all levels of the JLPT administered from 1999 to 2000 . There were four main findings; 1) setting and role were well-balanced and did not focus on a particular setting or role. But in lower levels, unclear setting and role were problematic. 2) In function, ideational functions (function for information and function for expression) covered $80 \%$ of all listening texts. 3) In text type, $70 \%$ of listening texts were conversation type text. 4) Various topics were used.

\section{1 はじめに}

これまでの日本語能力試験(以下 JLPT)問題分析に関する先行研究を見ると、OPI との相関関係やテ クストの数国的分析など贯的分析が多い。しかし、JLPT の問題項目を实際の日本語使用場面(コンテ クスト)から見たとき、どのような傾向があるのか、不自然な点はないのか、偏りはないのかなどの質 的分析はあまりなされていないようである。

ところで、人間は場面(コンテクスト)において言語を使用する。つまり場面(コンテクスト)なしには言語 使用はできない。TOEFL では場面(コンテクスト)を「状況」「人間関係」機能」「トピック」「テクスト」から 權成されているとしている。そして、この考えに基づき、これらの要秦の内容を設定し、問題を作成して いる(Chapelle et al, 1996)。

では、TOFEL は具体的にどのように「状況」「人間関係」「譏能」「トピック」「テクスト」を設定しているの だろうか。まず、「状況」は咅語行勒が起る坦所であり、具体的には(1)教育渨境(公的な教育が行われ 全ての埥所:教室など) (2アカデミック㜊境(教室外の典型的な場所;図专館など) (3)非アカデミック琭 境(アカデミックとは関連のない㭶所;衰の部屋など)である。「人間関係」は、言語行動に関わる人々や その人たちの関係であり、性別・民族・年椧・役割を考虑する。「譏能」は、Halliday の 7 つのカテゴリー のうち 6 つを(1)発見的(heuristic) (2)道具的(instrumental) (3)規制的(regulatory) (4)個人的(personal) (5)描写的 (representative) 6)対人的(interactional)使用している(7つ目のカテゴリー「㓣造的 (creative)」はTOEFL の筑囲を越えるものとして除外している)。「トピック」は、言語タスクに含まれる話 題のことであり、(1)アカデミック(自然科学と社会科学) (2)教室関連(大学の授莱に出席することや宿題 をすることのような学生が日常的に要求されること) (3)学科外(学生に高頻度で起ることだ、学業と は関係ないこと、病気や天気、ルームメ一トとの関係など)を扱う。「テクスト」タスクを達成するために使 われる言語の種類であり、(1)文法的特㮹(統語と語点) (2)語用論的特徵 (3)談話の特徵、の 3 つ特徵 から記述されている。

一方、JLPT「恥解」の出題基準(国際交流基金、1994)では「『学習者が出会う日常生活の中での課題』 に当るものを試験の課題として取り出し、その解決への取り組みを求める」とある。しかし、「常生活」 ではその指す箈囲が広く、また「状況」「「人間関係」・「話題」「「テクスト」・「機能」など多岐にわたるが、 「日常生活」に関する詳しい記述はない。例えば、同じ「日常生活」でも「自宅で(状況)家族(人間関係) とテレビドラマ(話題)について会話をする(機能)」と「地下鉄(状況)で駅虽(人間関係)と乗り換えの方法 
(話題)を事ねる(機能)」とでは、かなりの䢖いがある。

以上のように、「日常生活」ではその䈯囲が広すぎ、内部に多くの要素を抱えているので、これらの要秦 が変化すると、受験者は使用する能力も変わる。つまり、これらの要美を考虑に入れないと測ろうとす る能力を測ることができなくなってしまう可能性がある。

JLPT「聴解」はその出题基準を見る限りでは、上記の要搸をあまり考瓦していないようである。そのた め、現在の JLPT「恥解」の問題を、㙋面(コンテクスト)から分析してどのような頃向(偏り)が生じている

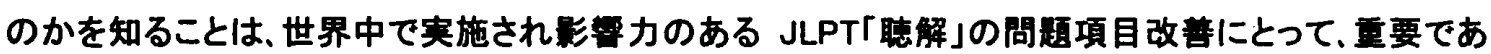
ると思われる。

本穤の目的は JLPT「恥解」のテクストが現実の日本語使用場面(コンテクスト)から見てどんな特徽を

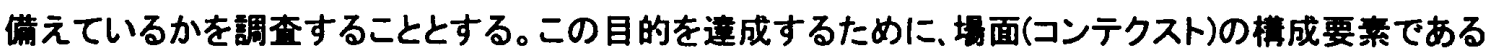
1)「状況(テクストがどんな坦所で閩かれうるか)」、2)「人間関係(テクスト内の登场人物はどんな人なの か)」、3)「機能(テクストがどんな目的(=機能)を持っているか」」4)「トピック(テクストがどんなトピック を扱って(るか)」、5)「テクストの程類」の钼点から分析する。

\section{2 明查の梅要}

\section{1 対象筫料}

1999 年度と 2000 年度の日本語能力試験「聴解」 1 級から 4 級の問题を調查対象にした。瓷料 は国際交流基金が毎年出版している「日本語能力試験分析評価に関する報告語」を使った。こ の報告書には日本語能力試験の問題分析結果があり、聴解問題についてはスクリブトと各問題 の状況設定(場所と登場人物の役割・年齢等)が書いてある。

\section{2 分析方法}

分析基準は「場面」の棈成要来である 1) 状況（setting）からの分析、2）人間関係(role)、3）機

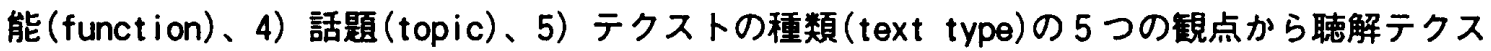
トの分析を行った。それぞれの分析基準については以下に詳しく記述する。

前述したが、「日本語能力試験分析評価に関する報告請」内にある聴解問題に関する問題分析 結果には、各問題のスクリブトと状況設定(場所と登場人物の役割・年齡等)が吾いてある(し かし、すべての問題ではない)。本稿の分析では、分析の信頼性を高めるため、1999年度と 2000 年度の報告書を利用し、基本的にこの報告㶳の分析結果に従ったが、一部の納得できない分析 結果や分析結果の記述がない問題については管者の分析を優先した。

\subsection{1. 状況 (set t ing) からの分析基泍}

無数にある状況を体系化する先行研究として、フィッシュマン(1973 ネウストプニー 1995 から引用)、Council of Europe (2001)、Association of Language Testers in Europe(ALTE) (Council of Europe (2001)から引用)、国立国語研究所（1980）がある。本稿では先行研究 を基に状況を体系化する枠組みを作成し（参考資料 1)、これを用いて分析を行った。 
上でも述べたが、状況は無限にあるので、それらを大きくまとめる概念が必要になる。本稿で 使用した枠組みを説明すると、上位概念として(1)「私的生活・個人」、(2)「外出先・社会的」、 (3)「教育」、(4)「職業」、(5)「メディア」に分け、それぞれの上位概念には複数の中位概念があ り、その下に具体的な状況を置いた（詳しくは参考資料 1 を参照)。

\subsection{2. 人間関係 $(\mathrm{role} \theta)$ からの分析基染}

人間関係は「年齡」「性別」「役割」「地位」など多くの要秦がお互いに絡まりあい、複雑であ る。数多くの要素をどう分類するかも简単ではない。実際に問題を分析した結果、対話文の場 合ほとんど男女の組み合わせであり、また、年齡も登場人物の声質から判断せざるを得ないこ ともあり、本稿では登場人物の「社会的役割」(例:学生や会社員など)に注目し、分析するこ とにした。

「社会的役割」を分析基準にはしたが、「社会的役割」の何らかの基準を作成することが難し かった。そのため、基準を作らず、調查結果を見てから、その結果から何らかの判断を下すこ とにした。

\subsection{3. 樴能(function) からの分析基㲚}

機能リストの先行研究として、森泉 (1991)、ザトラウスキー（1991）、日本語教育学会 (1991)、 韓国教育人材資源部 (1997)、van EK and Trim（1991）、鈴木·筒井 (2000) - 2001）、谷口(1989)、 Wilkins、D.A. (1984)、尾崎 (1996) がある。既存の機能リストを分析した結果、6つの共通機能 項目（1）情報伝達、2）自己表出（感情・意図・態度・意思）、3）働き掛け(行為・情報）、4）社会 生活・人間関係、5) コミュニケーションストラテジー(CS)、6)談話・会話の談話)を得た。こ の共通機能項目の中にある 5) CS は、機能というより一般能力の一部として扱う(Bachman、1990) ことが最近の議論での主流であるので、ここでは機能として取り扱わない方が良いと判断した。 また、6)談話・会話の談話は、それ自体では機能としては存在しないので、これも機能として扱 わないことにした。次に取り出せた機能項目をまとめるために、ハリディの理論を基にしてい る Bachman(1990)のモデルを利用した。上位機能として「観念」と「操作」があり、「観念」の 下には中位機能として 1)情報と 2) 自己表出を置き、「操作」の下には 3)人間関係と 4)働きか けを置いた。そして 4 つの中位機能の下にまた下位機能を置いた(詳しくは参考資料 2 を参照)。

このようにして作成した機能リストで、問題分析をしたが、機能の認定は難しい。特に会話で は複数の機能が使われるため、すべての機能を取り出すのかそれとも中心的な機能だけ取り出 すのかといった問題に直面する。

本稿では複数の機能があっても、その中で中心的な機能を摘出することにした。その理由は 2 つある。まず、すべての機能を取り出すと、データが煩雑になって、テクストの特徵が出ない。 また、対話では一方の人が情報を求めれば、相手は情報を与える、という、大枠で同じような 機能を使用することが多いからである。 


\subsection{4. テクストの程類(text type) からの分析基滓}

テクストの種類は、統語や語集、談話の形式など色々な側面から捉えることが出来るが、 Council of Europe (2001) と日本語教育学会(1991 年)の先行研究を基に、テクストの種類の分 析基準を作った。

分析基準は、(1)公衆アナウンス・作業などの指示や命令、(2)スピーチや講義、(3)儀式(式・宗教的 儀式)、(4)エンターティメント(娛楽番組・ドキュメンタリー番組・スポーツ解説)、(5)コマーシ ヤル、(6)ニュース、(7)話し合い、(8)会話(雑談)、(9)電話の会話、(19就職の面接、の11 項目を立 てた(詳しくは参考瓷料 3 )。

\subsection{5. 話題(topic) からの分析基蓝}

話し言葉における話題の関する先行研究は、Council of Europe (2001) と国立国語研究所 (1980) がある。ただし、後者の先行研究は大学の教員や学生の一日の言語行動を基にしたもので、一 般的ものとはいえない。本研究ではCouncil of Europe (2001)の先行研究を中心にし、そこに 国立国語研究所（1980）の研究結果を加味する形で話題のリスト作成した。そしてそのリスト を基に問題分析を行った。

話題としては以下の 15 のトピックを選定した。1)個人の確認、2) 家・地域・環境、3）仕 事、4）自由時間・娛楽、5）旅行・交通、6）時事、7）健康と身体的管理・育児、8）教 育、9）買い物、10）饮食物、11）サービス機関、12）場所、13）天気、14）他人との関係、15） 家庭・家族関係、16）日本文化・習惯（詳しくは参考瓷料 4 ）。

\section{3 结果}

この章では、前章で述べた5つの分析項目によるJLPT「聴解」(1999-2000)の全問題の分析結果 を述へる。まず、分析項目による全体の結果を報告し、それから級別の結果に言及する。

\section{1. 全体の结果}

\subsection{1. 状況}

状況の分析基準は上位概念として5区分し、その下に中位概念を置き、1つ1つの䁃解問題が設定し ている状況がどこであるかを分析した(表1を参照)。分析結果を見ると、外出先(60問·28\%)がー 番多く、次に職業 (44問·21\%)、メディア(34問・16\%)と続く。また、不明とされた問題が24問 (11\%)になった。

次に、より詳しい㑯向を得るために、状況の上位概念の下にある中位概念ごとに結果を見た。上位概 念(1)私的生活·個人」には3つの中位概念があるが、JLPT の聴解問題は1) 自分の家 (30問・1 4\%)だけで占められていることが分かった。また上位概念(2)「外出先·社会的」は12の中位概念から

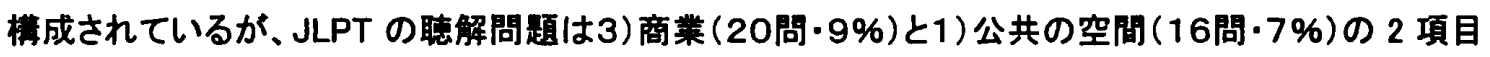
で外出先内の半分を占める。上位概念(4)「教育」は1)公的教育 (18問·8\%)が多く、上位概念(5)「 ディア」では1)テレビ·ラジオが24問(11\%)と多いことが分かった。 


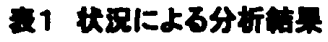

\begin{tabular}{|c|c|}
\hline $\begin{array}{c}\text { 上位概念 } \\
\text { (問题数·\%) }\end{array}$ & 中位根念(問题数·\%) \\
\hline \multirow{3}{*}{$\begin{array}{l}\text { (1)私的生活·固人 } \\
\text { (30夙·14\%) }\end{array}$} & 1)自分の家（30問·14x） \\
\hline & 2)寨やアパート（0問·0x） \\
\hline & 3)ホテル(0同·0*) \\
\hline \multirow{12}{*}{$\begin{array}{l}\text { (2)外出先 } \cdot \text { 社会的 } \\
(60 \text { 風 } \cdot 28 \%)\end{array}$} & 1)公共の空間(16問·74) \\
\hline & 2)公共交通機関(3問·1x) \\
\hline & 3)商菜 (20問·9x) \\
\hline & 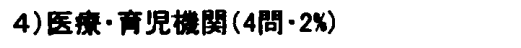 \\
\hline & 5)スポーツ施設(4問·2x) \\
\hline & 6) 文化施設(5周·2x) \\
\hline & 7）社交場(0闾-0x) \\
\hline & 8) 宗教 (0同·0x) \\
\hline & 9)旅行 - 银光 (2問· 1 \\
\hline & 10）施同先(1問・0x) \\
\hline & 11) 安全·保全(1問·0\%) \\
\hline & 12）公共機関 (4問·2x) \\
\hline \multirow{2}{*}{$\begin{array}{l}\text { (3)教育 } \\
\text { (22問·10\%) }\end{array}$} & 1)公的学校(18栭 - $8 \%)$ \\
\hline & 2)各程学校 (4閣·2x) \\
\hline \multicolumn{2}{|l|}{ 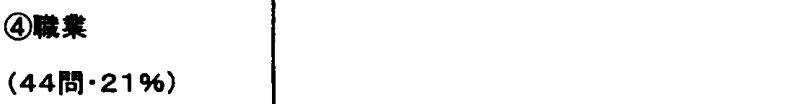 } \\
\hline \multirow{2}{*}{$\begin{array}{l}\text { (5)メティア } \\
(34 \text { 同・16\%) }\end{array}$} & 1)テレビ・ラジオ （24問・11\%) \\
\hline & 2)蛋話・电子メール・手紙 (10成・5\%) \\
\hline $\begin{array}{l}\text { 不明 } \\
(24 \text { 問·11\%) }\end{array}$ & \\
\hline
\end{tabular}

\subsection{2. 人间间保}

人間関係による分析結果は、多様な役割を持った人物が登場したため、特定の役割に絞れず、その 他が95問 (45\%)になつた。その中で比较的多く登場した役割が、同僚(25問・12\%)、学生 2 名(1 6問·7\%)、知以合い 2 名(15問7\%)が挙げられる。

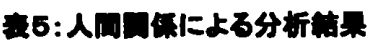

\begin{tabular}{|c|c|c|c|c|c|c|c|c|c|c|}
\hline 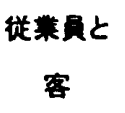 & $\begin{array}{l}\text { 等生 } \\
2 \text { 名 }\end{array}$ & 歎子 & $\begin{array}{c}\text { 知り合い } \\
2 \text { 名 }\end{array}$ & $\begin{array}{l}\text { 友人 } \\
2 \text { 名 }\end{array}$ & $\begin{array}{l}\text { 上司と } \\
\text { 部下 }\end{array}$ & $\begin{array}{c}\text { アナウン } \\
\text { サー }\end{array}$ & 同嫊 2 名 & 嗮的 & その地 & 合就 \\
\hline $10(5 x)$ & $16(7 x)$ & $12(6 \%)$ & $15(7 x)$ & $14(7 x)$ & $7(3 \%)$ & $8(4 \%)$ & $25(12 x)$ & $11(5 x)$ & $96(45 \%)$ & $214(100 \%)$ \\
\hline
\end{tabular}




\subsection{3. 的野}

JLPT 聴解問題を機能の面から分析すると、どんな傾向があるかを調べた(表2を参照)。機能を上 位·中位·下位の3階居にして分類したが、まず上位機能から見ると、情報と自己表示という钼念機能 だけで全体の8割を占めることが明らかになった。次に中位機能で見ると、情報 (102問·48\%)が全 体の半分近くを占め、自己表示(68問·32\%)、㑬きかけ(33問·15\%)と続く。人間関係はわずか 2 問 (1\%)しかない。樶後に下位機能から見ると、情報は(2)「説明」が 67 問、(1)知らせるが35問であつ た。自己表出は(1)「意図」がー番多く42問、次に(3「態度」が10問と続く。人間関係はす「感誎」が2 問であり、動きかけは8「「要唯・依頼など」が15問と一番多い。

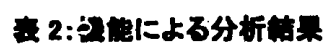

\begin{tabular}{|c|c|c|}
\hline 上位 & 中位 & 下位 \\
\hline \multirow{3}{*}{ 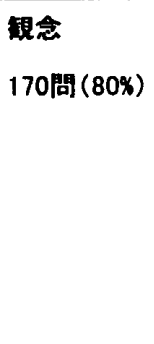 } & 1)情啹 & (1)知らせる：35(16\%) \\
\hline & $102(48 x)$ & (2)説明: $67(31 x)$ \\
\hline & $\begin{array}{l}\text { 2)自己㒇出 } \\
\text { 68(32x) }\end{array}$ & 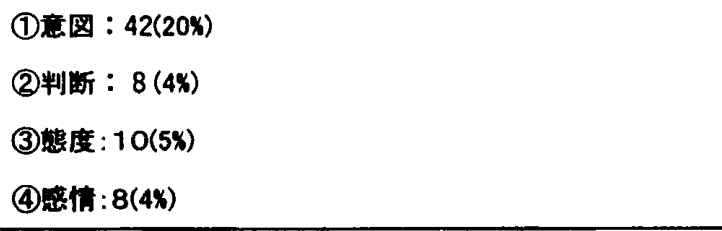 \\
\hline \multirow[t]{2}{*}{$\begin{array}{l}\text { 操作 } \\
\text { 35問(16\%) }\end{array}$} & $\begin{array}{l}\text { 3)人間関係 } \\
2(1 x)\end{array}$ & 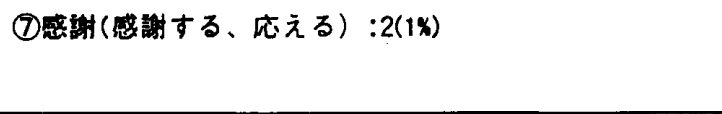 \\
\hline & $\begin{array}{l}\text { 4)何きかけ } \\
\text { 33(15\%) }\end{array}$ & 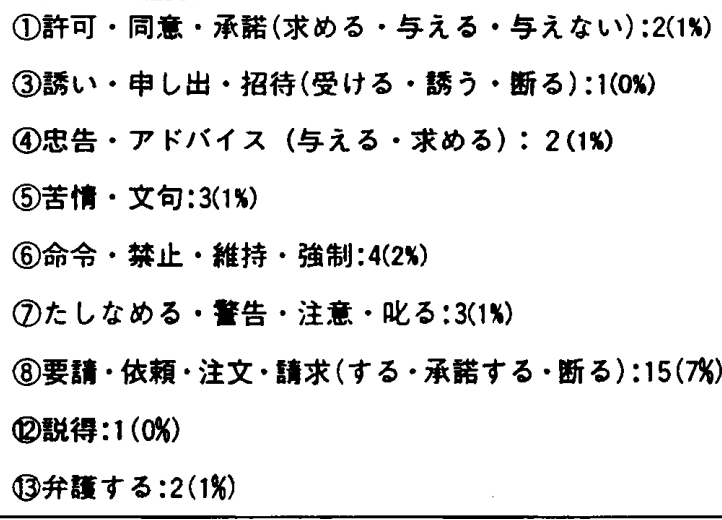 \\
\hline \multirow{2}{*}{$\begin{array}{l}\text { その他 } \\
9(4 \%)\end{array}$} & 重被8(4x) & \\
\hline & 不明1(0x) & \\
\hline 合㖕 & \multicolumn{2}{|l|}{$214(100 x)$} \\
\hline
\end{tabular}

注:問顆数 (全体から見たパーセント)

\subsection{4. テクストの淔類}

テクストの種類として12種類を選定して、JLPT 聴解問題を分析した。結果は会話テクストが全体の7 2\%(154 問)を占め、次にスピーチや䍀嶬といった発話者がー人でまとまった談話量がある発話テク ストが次に多い(37問・17\%)ことが分かった。 


\begin{tabular}{|c|c|c|c|c|c|c|c|}
\hline $\begin{array}{l}\text { 1)公衆アナ } \\
\text { ウンスなど }\end{array}$ & $\begin{array}{l}\text { 2)スピーチ・ } \\
\text { 諢鐘など }\end{array}$ & $\begin{array}{l}\text { 4)エンターテ } \\
\text { 1メント }\end{array}$ & 6)ニュース & 7)話し合い & 8)会話 & 9)電話 & 合計 \\
\hline $8(4 \%)$ & $37(17 \%)$ & $1(0 \%)$ & $2(1 \%)$ & $6(3 \%)$ & $154(72 \%)$ & $6(3 \%)$ & $214(100 \%)$ \\
\hline
\end{tabular}

注:問題数 (全体から見たパーセント)

\subsection{5. トピック}

トピツクで分析するため、17の分析項目を立てた。分析結果からは、JLPT 恥解問題全体として特定 の話題には集中していないことが明らかになった。その中で、3)仕事 (23問・11\%)、4)自由時間· 娛楽 (18問·8\%)、9）買い物（14問・7\%)に関するトピックが比較的多く用いられていることが分か った。

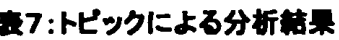

\begin{tabular}{|c|c|c|c|c|c|c|c|}
\hline 1)個人の確認 & $\begin{array}{l}\text { 2）家·地域· } \\
\text { 環境 }\end{array}$ & 3)仕事 & $\begin{array}{l}\text { 4) 自由 時 } \\
\text { 間·㜏楽 }\end{array}$ & $\begin{array}{l}\text { 5)旅行 } \cdot \text { 交 } \\
\text { 通 }\end{array}$ & $\begin{array}{l}\text { 6) 時 } \\
\text { 事 }\end{array}$ & $\begin{array}{l}\text { 7) 健康と身体 } \\
\text { 管理·育児 }\end{array}$ & 8)教育 \\
\hline $13(6 \%)$ & $17(8 x)$ & $23(11 \%)$ & $18(8 \%)$ & $11(5 \%)$ & $5(2 x)$ & $13(6 \%)$ & $8(4 x)$ \\
\hline
\end{tabular}

\begin{tabular}{|c|c|c|c|c|c|c|c|}
\hline 9)買い物 & 10）㰩食物 & 11)サービス機関 & 12)坦所 & 13)天瓷 & $\begin{array}{l}\text { 14)他人との } \\
\text { 関係 }\end{array}$ & $\begin{array}{l}\text { 15)家庭 } \\
\text {-家族関係 }\end{array}$ & $\begin{array}{l}\text { 16)日本文化 } \\
\text { ·習惧 }\end{array}$ \\
\hline $14(7 x)$ & $10(5 x)$ & $4(2 x)$ & $12(6 \%)$ & $3(1 x)$ & $4(2 x)$ & $11(5 \%)$ & $5(2 x)$ \\
\hline
\end{tabular}

\begin{tabular}{|c|l|l|}
\hline 17)日·時間 & 不明 & 合計 \\
\hline $13(6 \%)$ & $30(14 \%)$ & $214(100 \%)$ \\
\hline
\end{tabular}

注:問題数 (全体から見たパーセント)

\section{2. 影別による分析结果}

3.1.では分析基準別に JLPT 全体の特幑を提示したが、ここでは級別の傾向に関する分析結果を報 告する。

\subsection{1. 状況}

状況による級別分析結果を表8に示した。結果から、まず2)「外出先」がすべての級で 30\%近くを占 めていることがわかる。次に、5)「メディア」の割合は級が上がるごとに高くなり、6)「不明」が下位級 ほど多くなことが分かる。

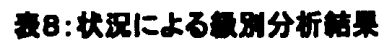

\begin{tabular}{|c|c|c|c|c|c|c|c|}
\hline & 1)私的生活 & 2)外出先 & 3)教育 & 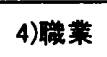 & 5)メディア & 6)不明 & 合㖕 \\
\hline 1 級 & $12(18 x)$ & $18(27 x)$ & $4(6 x)$ & $19(28 x)$ & $14(21 x)$ & $O(0 x)$ & $67(100 \%)$ \\
\hline 2 級 & $6(10 x)$ & $15(26 \%)$ & $8(14 \%)$ & $14(24)$ & $11(19 x)$ & $4(7 x)$ & $58(100 x)$ \\
\hline 3 极 & $11(22 x)$ & $15(30 \%)$ & $6(12 x)$ & $5(10 \%)$ & $5(10 \%)$ & $8(16 \%)$ & $50(100 \%)$ \\
\hline
\end{tabular}




\begin{tabular}{|c|c|c|c|c|c|c|c|}
\hline 4 极 & $5(13 \%)$ & $12(31 x)$ & $4(10 \%)$ & $8(21 x)$ & $4(10 x)$ & $6(15 \%)$ & $39(100 x)$ \\
\hline
\end{tabular}

注:問題数（全体から見たパーセント）

\subsection{2. 桠鹤}

機能による級別分析結果は表9に示したとおりである。下位級では1)「情報」が2)「自己表示」より多 いが、上位級になるとそれが逆転している。また、3)「人間関係」は上位級にしか現れていない。更に、 4)「值きかけ」は下位級に比較的多く使用されている。

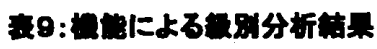

\begin{tabular}{|c|c|c|c|c|c|c|c|}
\hline & 1 悄郝 & 2 自己表示 & 3 人間関係 & 4 的きかけ & 5 吾柆 & 6 不明 & 合部 \\
\hline 1 級 & $26(39 x)$ & $28(42 x)$ & $1(1 x)$ & $7(10 \%)$ & $4(6 \%)$ & $1(1 \times)$ & $67(100 \%)$ \\
\hline 2 极 & $27(47 x)$ & $19(33 \%)$ & $1(2 x)$ & $9(16 \%)$ & $2(3 x)$ & & $58(100 \%)$ \\
\hline 3 級 & $25(50 x)$ & $14(28 x)$ & & $9(18 \%)$ & $2(4 x)$ & & $50(100 x)$ \\
\hline 4 級 & $24(62 x)$ & $8(21 x)$ & & $7(18 \%)$ & & & $39(100 x)$ \\
\hline
\end{tabular}

注:問類数(全体から見たパーセント)

\subsection{3. 人间成保}

人間関係による級別分析結果は表 10 に示した。1 級ではアナウンサー(5問・7\%)、部長 (4問・6\%) 䍀師 (6 問·9\%)の単独の発話が多く、情報を上から下にもらうという上下関係が目立つ。2 級は学生 (6問·10\%)、夫㛿(6問·10\%)が比較的多い。3 級は学生 (6問・12\%)、親子(7問14\%)、友人 (6問・12\%)、夫媂(7問・14\%)といった親しい関係が多い。4 級は知り合い(10問·26\%)、友人(4 問10\%)、同僚 (7問・18\%)といった平等な関係が多いことが分かった。

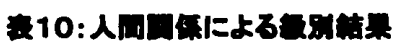

\begin{tabular}{|c|c|c|c|c|c|c|c|c|c|c|c|c|c|}
\hline & $\begin{array}{l}\text { 従菜員 } \\
\text { と客 }\end{array}$ & $\begin{array}{l}\text { 学生 } \\
2 \text { 名 }\end{array}$ & 親子 & $\begin{array}{l}\text { 知り } \\
\text { 合い } \\
2 \text { 名 }\end{array}$ & $\begin{array}{l}\text { 友人 } \\
2 \text { 名 }\end{array}$ & $\begin{array}{l}\text { 上司 } \\
\text { と部 } \\
\text { 下 }\end{array}$ & $\begin{array}{l}\text { アナ } \\
\text { ウン } \\
\text { サー }\end{array}$ & $\begin{array}{l}\text { 部 } \\
\text { 長 }\end{array}$ & 夫炼 & $\begin{array}{l}\text { 同借 } \\
2 \text { 名 }\end{array}$ & 端師 & その他 & 合計 \\
\hline $\begin{array}{c}1 \\
\text { 級 }\end{array}$ & $\begin{array}{c}3 \\
(4 x)\end{array}$ & $\begin{array}{c}2 \\
(3 x)\end{array}$ & $\begin{array}{c}4 \\
(6 \%)\end{array}$ & $\begin{array}{c}1 \\
(1 x)\end{array}$ & $\begin{array}{c}3 \\
(4 \times)\end{array}$ & $\begin{array}{c}4 \\
(6 \times)\end{array}$ & $\begin{array}{c}5 \\
(7 x)\end{array}$ & $\begin{array}{c}4 \\
(6 x)\end{array}$ & $\begin{array}{c}7 \\
(10 x)\end{array}$ & $\begin{array}{c}7 \\
(10 x)\end{array}$ & $\begin{array}{c}6 \\
(9 x)\end{array}$ & $\begin{array}{c}21 \\
(31 x)\end{array}$ & $\begin{array}{c}67 \\
(100 x)\end{array}$ \\
\hline $\begin{array}{c}2 \\
\text { 般 }\end{array}$ & $\begin{array}{c}4 \\
(7 x)\end{array}$ & $\begin{array}{c}6 \\
(10 x)\end{array}$ & $\begin{array}{c}3 \\
(5 \times)\end{array}$ & $\begin{array}{c}3 \\
(5 \%)\end{array}$ & $\begin{array}{c}1 \\
(2 x)\end{array}$ & $\begin{array}{c}2 \\
(3 x)\end{array}$ & $\begin{array}{c}1 \\
(2 x)\end{array}$ & & $\begin{array}{c}6 \\
(10 \%)\end{array}$ & $\begin{array}{c}7 \\
(12 x)\end{array}$ & $\begin{array}{c}5 \\
(9 x)\end{array}$ & $\begin{array}{c}20 \\
(34 x)\end{array}$ & $\begin{array}{c}58 \\
(100 \%)\end{array}$ \\
\hline $\begin{array}{c}3 \\
\text { 級 }\end{array}$ & $\begin{array}{c}2 \\
(4 x)\end{array}$ & $\begin{array}{c}6 \\
(12 x)\end{array}$ & $\begin{array}{c}7 \\
(14 \%)\end{array}$ & $\begin{array}{c}2 \\
(4 x)\end{array}$ & $\begin{array}{c}6 \\
(12 x)\end{array}$ & $\begin{array}{c}1 \\
(2 x)\end{array}$ & $\begin{array}{c}2 \\
(4 x)\end{array}$ & & $\begin{array}{c}7 \\
(14 x)\end{array}$ & $\begin{array}{c}4 \\
(8 \%)\end{array}$ & & $\begin{array}{c}13 \\
(26 \%)\end{array}$ & $\begin{array}{c}50 \\
(100 \%)\end{array}$ \\
\hline $\begin{array}{l}4 \\
\text { 級 }\end{array}$ & & $\begin{array}{c}1 \\
(3 x)\end{array}$ & $\begin{array}{c}1 \\
(3 x)\end{array}$ & $\begin{array}{c}10 \\
(26 \%)\end{array}$ & $\begin{array}{c}4 \\
(10 x)\end{array}$ & & & & $\begin{array}{c}2 \\
(5 \%)\end{array}$ & $\begin{array}{c}7 \\
(18 \times)\end{array}$ & & $\begin{array}{c}14 \\
(36 \%)\end{array}$ & $\begin{array}{c}39 \\
(100 \%)\end{array}$ \\
\hline
\end{tabular}

注:問题数（全体から見たパーセント）

\subsection{4. テクストの程祖}

テクストの種類による級別分析結果は表11に示したとおりである。上級級ではスピーチや满静タイプ が多く、下位級では会話タイプが多くなることが明らかになった。 


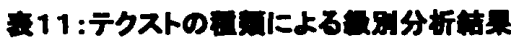

\begin{tabular}{|c|c|c|c|c|c|c|c|c|}
\hline & $\begin{array}{l}1 \text { 公衅アナウ } \\
\text { ンスなど }\end{array}$ & $\begin{array}{l}2 \text { スピーチ・ } \\
\text { 鄁灌など }\end{array}$ & $\begin{array}{l}4 \text { エンターテイメ } \\
\text { ント }\end{array}$ & $6=ュ ー ス$ & $\begin{array}{l}7 \text { 話し合 } \\
\text { い }\end{array}$ & 8 会話 & 9 電話 & 合㖕 \\
\hline 1 䋇 & $1(1 x)$ & $20(30 x)$ & $1(1 x)$ & 0 & $4(6 \dot{x})$ & $39(58 x)$ & $2(3 x)$ & $67(100 \%)$ \\
\hline 2 級 & $3(5 \%)$ & $10(17 x)$ & 0 & $1(2 \%)$ & $1(2 x)$ & $41(71 x)$ & $2(3 x)$ & $58(100 \%)$ \\
\hline 3級 & $2(4 x)$ & $4(8 x)$ & 0 & 0 & 0 & $41(82 x)$ & $3(6 \%)$ & $50(100 \%)$ \\
\hline 4 級 & $3(8 \%)$ & $3(8 \%)$ & 0 & $1(3 x)$ & $1(3 x)$ & $31(79 x)$ & 0 & $39(100 \%)$ \\
\hline
\end{tabular}

注: (問題数·全体から見たパーセント)

\subsection{5. トピック}

トピックによる級別分析結果は、表12のとおりである。上位級では3)「仕事」(1 級: 12問・18\%、2 級: 9問·16\%)や16)「日本文化·習偩」(3.4級では扱われていない)が多い。一方、下位級では、 1)「個人の確認」(3級: 4 問·8\%、4 級:5問·13\%)、4)「自由時間や娛楽」(3級: 7問· $14 \% 、 4$ 級: 4問·10\%)、10)「钦食物」(1・2級では扱われていない)が多いことが分かった。

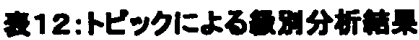

\begin{tabular}{|c|c|c|c|c|c|c|c|c|}
\hline & $\begin{array}{c}1 \text { 栶人の } \\
\text { 確鲃 }\end{array}$ & $\begin{array}{c}2 \text { 家·地找・ } \\
\text { 理境 }\end{array}$ & 3 甘事 & $\begin{array}{c}4 \text { 自由時間- } \\
\text { 㧹楽 }\end{array}$ & 5 旅行·交通 & 6 時事 & $\begin{array}{c}7 \text { 健康と身体管 } \\
\text { 理·育览 }\end{array}$ & 8 教育 \\
\hline 1 級 & $1(1 \%)$ & $5(7 x)$ & $12(18 x)$ & $5(7 x)$ & $4(6 \%)$ & $5(7 x)$ & $2(3 x)$ & $2(3 x)$ \\
\hline 2 級 & $3(5 \%)$ & $7(12 x)$ & $9(16 x)$ & $2(3 x)$ & 0 & 0 & $6(10 \%)$ & $4(7 \%)$ \\
\hline 3 級 & $4(8 \%)$ & $4(8 x)$ & $2(4 \%)$ & $7(144)$ & $2(4 \%)$ & 0 & $2(4 \%)$ & $1(2 x)$ \\
\hline 4 級 & $5(134)$ & $1(3 x)$ & $1(3 \%)$ & $4(10 \%)$ & $5(13 x)$ & 0 & $3(8 \%)$ & $1(3 \%)$ \\
\hline
\end{tabular}

\begin{tabular}{|c|c|c|c|c|c|c|c|}
\hline 9 䨘い物 & 10 领食物 & 11 サービス機関 & 12 畦所 & 13 天妄 & $\begin{array}{c}14 \text { 他人との } \\
\text { 関係 }\end{array}$ & $\begin{array}{c}15 \text { 家庭 } \\
\text { •家族関係 }\end{array}$ & $\begin{array}{c}16 \text { 日本文化 } \\
\text { 習俋 }\end{array}$ \\
\hline $3(4 x)$ & 0 & $2(3 x)$ & $2(3 x)$ & 0 & $4(6 \%)$ & $6(9 \%)$ & $4(6 \%)$ \\
\hline $4(7 x)$ & 0 & $1(2 x)$ & $6(10 \%)$ & $2(3 x)$ & 0 & $2(3 x)$ & $1(2 x)$ \\
\hline $6(12 x)$ & $3(6 x)$ & $1(2 x)$ & $2(4 x)$ & 0 & 0 & $2(4 x)$ & 0 \\
\hline $1(3 x)$ & $7(18 x)$ & 0 & $2(5 \%)$ & $1(3 x)$ & 0 & $1(3 x)$ & 0 \\
\hline
\end{tabular}

\begin{tabular}{|c|c|c|}
\hline 17 日·時間 & 不明 & 合甜 \\
\hline $4(6 x)$ & $6(9 x)$ & $(100 x)$ \\
$4(7 x)$ & $7(12 x)$ & $(100 x)$ \\
$2(4 x)$ & $12(24 x)$ & $(100 x)$ \\
\hline $3(8 x)$ & $4(10 x)$ & $39(100 x)$ \\
\hline
\end{tabular}

注: (周趩数·全体から見たパーセント)

\section{4 考宗}

3章で得た分析結果を踏まえて、この章では結果から、場面(コンテクスト)から見たJLPT聴解問題の 
特徵について逨へたたい。ここでも分析項目順に諱論を進める。

\section{1. 状況}

全体的に見ると、いろいろな状況がバランスよく使用されていると言えるが、あえて問题点を2点指摘 する。

上位概念間はバランスがよいが、上位概念内にある中位概念を見ると、特定の中位概念が集中して 使われている傾向がある。従って、できれば他の状況も使用し、状況の多様さを維持することが望ま しい。

次に下位級で目立つ「不明」である。「不明」というは、その愳解問題が特定な状況を設定していない と判断したためである。もちろん、すべての発話が状況とのつながりがあるわけではない(例えば、学 生同士がアルパイトの話をする埸合、その状況が学校でも喫茶店でも車車の中でも多様な状況で行 える)。しかし、「不明」と判断される項目が多いのは、望ましいことは言えない。

ネウストプニー(1996)によると、コミュニケーションをしようとする時、人間は a）コミュニ ケーションの目襌（=「機能」）b）コミュニケーションのセッティング（時䦓と場所）c）コ ミュニケーションの参加者 d）コミュニケーションの内容 の要秦を考虑に入れてから、コミ ュニケーションを開始すると述べている。これは言い換えれば、a)-d）の要素があって初めて コミュニケーションができるということである。これらの要来を無視して問題を作成すること は、言語コミュニケーションにおけるコンテクストを無視することであり、機能のところでも速 べるが、「意味の理解」という面を重視しすぎていることになる。つまり、言語情報だけでなく、外界の 非官語情報も取り入れながら、コミュニケーションをする実際の言語使用の現実を反映していない。

下位級の埸合、非莒語的要棠が確実に設定されてある方が、分かりやすい。従って、下位級では、状 況と密接に結びついているセットフレーズ的なものを出題し、上位級では状況から離れた抽象的な場 面を扱った方がい。

\section{2. 人间国保}

JLPT「聴解」は、全体的には様々な人間関係を扱っている。しかし、下位級にある「知り合い」(3 級: 2 問·4\%、4 級: 10問·26\%)、「友人」(3 級: 6 問·12\%、4 級:4問·10\%)、「同僚」(3 級:4問·8\%、4 級: 7問·18\%)という人閔関係は、かなり曖昧な人間関係である。ここでも、「意味の理解」重視のた め、人間関係が無視されている。下位級ほど、知り合い、友人、同僚といった人間関係が多いことは、 現实の場面とのつながりがない空的な問題が多いことを示している。下位級は予め登埥人物がど んな人が説明してある問題の方が、テクストの理解だけでの問題より、分かりやすくなると思う。

\section{3. the}

情報と自己表示という钼念的機能だけで全体の80\%を占めていることは、それだけ JLPTが意味の 理解」を重視していることを示す。言っていることが理解できるかどうかを測定しようとしており、発話 の意図を汲み取るような設問がないと予想できる。発話の意味を理解するだけでなく、発話に反応し 
てなんらかの行動を起こさなければならないことが、現実の言語使用にはある。こういった言語能力 を測定するためには、現在の「意味の理解」重視では不十分である。

また人間関係の機能が下位級では扱われていなかった。しかし、多くの初級教科書では日常生活で 人間関係を維持するために必要な挨拶といった表現をまず学習する。従って、下位級ではより積極的 に人間関係機能を測定するようにすべきである。

\section{4. テクストの看類}

会話と講演・プレゼンテーションが多いので、もつと多様性があってもよい。特に上位級で講演・プレゼ ンテーションが増えるのは、長い談話の理解を測定するためだと思われる。

\section{5. トピック}

分析項目が多すぎたため、データが分散してしまい、これといった特徴を掴むことができなかった。

\section{5. 地辞に}

JLPT「聴解」テクストが場面(コンテクスト)の視点から見た時、どんな特徵を備えているのかを調查す ることが、本稿の目的であった。調查結果から、JLPT「聴解」のテクストは、「機能」の点で観念的機 能に偏っていること、その他の点では場面を明確に設定していない項目がー部に見受けられたことが 明らかになった。これらは、JLPT「聴解」が「意味の理解」を重視していることの現れであるといえる。

ただし、分析基蕉は先行文献を参考に個人的に作成したものであり、より改菩が必要である。また、 分析基準が变更されれば、当然その分析結果も変わるであろう。また、分析も基本的に国際交流基 金の分析報告要によった(一部納得がいかない部分は筆者の判断を優先)が、しかし、できれば被数 の判定者によって行われるべきである。これらのことは今後の課題としたい。

\section{参考文献}

Bachman、L.F.（1990) Fundamental Considerations in Language Testing. OUP. (池田央·大友賢二監 修言語テスト法の基䃈 みくに出版)

Chapelle. C. Grabe. W. and Berns. M. (1997) Communicative Language Proficiency: Definition and Implication for TOEFL 2000. 入手可能:http://www.toefl.org/pubs/resdloadlib.html

Council of Europe (2001) Framework of Reference for Languages: Learning, teaching, assessment. CUP

韓国教育人材資源部 (1997) 第7次日本語科教育課程「外国語科教育課程】(教育部告示第 1997-15

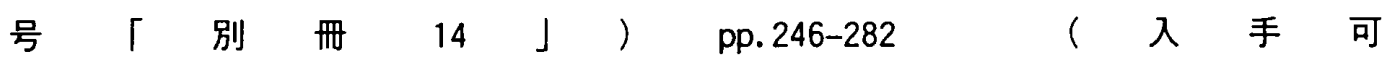

能:ht tp://www. jpf.go.jp/j/urawa/world/kunibetsu/syl labus/sy_e_asia.html)

国立国語研究所（1980）「日本人の知識階層における話しことばの実態」(科学研究費研究報告

毒. 研究代表者・野元菊雄. 資料編「場面について」担当者・日向茂男、杉戸 清樹）

国際交流基金（1994）日本語能力試験出題基準、凡人社

国際交流基金 (2000)平成 11 年度日本語能力試験分析評価に関する報告書

国際交流基金（2001）平成 12 年度の日本語能力試験分析評価に関する報告書 
ネウストプニー、J.V. （1995）新しい日本語教育のために 大修館茟店 ネウストプニー、J.V. (1996)「コミュニケーションとは何か」「日本語学」6月号 Vol18 明治 毒院 P $4-16$

日本語教育学会編 （1991）日本語教育機関におけるコースデザイン 凡人社

森泉朋子 (1991) 機能シラバスから観たICJ 初級教科書 拓殖大学日本語紀要第 1 号 p92-103 尾崎明人 (1996) 会話教育のシラバス再考一会話の展開と問題処理の技術を中心に一

「日本

語・日本文化論集」第 4 号 p119-135

鈴木睦・筒井佐代 （2000）日本語機能文型一管（試用版）（1）「多文化共存時代の言語教育」

(2) 平成 12 年度教育研究学内特別経喾プロジェクト研究報告言

鈴木睦・筒井佐代 （2001）日本語機能文型一監（試用版）（2）「多文化共存時代の言語教育」

(3) 平成 13 年度教育研究学内特別経費プロジェクト研究報告音

谷口すみ子(1989) 会話教育のシラバス作りに向けてー会話の技術のリスト試案 谷ロすみ子

「日本語教育」 68 号. p259-266.

van EK and Trim (1991) THRESHOLD LEVEL 1990（米山朝二・松沢伸二訳 新しい英語教育へ の指針 大修館當店）

Wilkins、D.A. (1984) Notional Syllabus. OUP. (島岡丘 訳 ノーショナルシラバス 桐原書 店)

ザトラウスキー、ボリー（1991）会話分析における「単位」についてー「話段」の提案「日 本語学】第 10 巻 10 号

\section{套等料}

参考稘料 $1 ：$ 状況の分析基浑

\begin{tabular}{|c|c|c|}
\hline 上位视念 & 中位社念 & 忩体的な状況 \\
\hline \multirow{3}{*}{$\begin{array}{l}\text { (1)私的生 } \\
\text { 活/国人 }\end{array}$} & 1) 自分の家 & 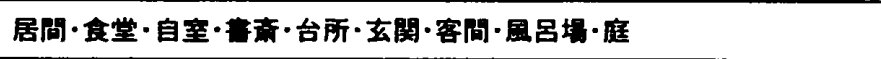 \\
\hline & 2) 䯨やアパート & 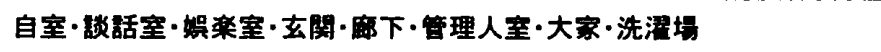 \\
\hline & 3)ホテル & \\
\hline \multirow{8}{*}{$\begin{array}{l}\text { (2)外出先 } \\
\text { / 杜会的 }\end{array}$} & 1)公共の空間 & 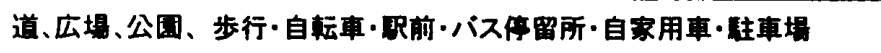 \\
\hline & 2)公共交通機関 & 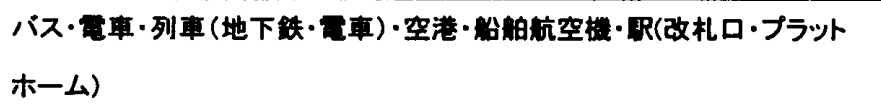 \\
\hline & 3)商粪 & 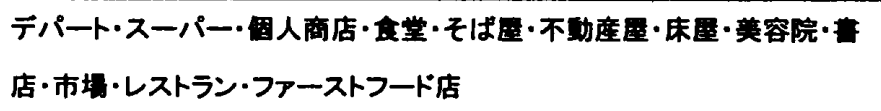 \\
\hline & 4）医療·育児機関 & 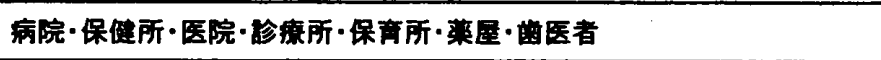 \\
\hline & 5)スポーツ施設 & 競技㛫、fields、ホール \\
\hline & 6) 文化施設 & $\begin{array}{l}\text { 㓟埸・映画館・エンターテイメント・レストラン・バブ・ホテル・ } \\
\text { 室 }\end{array}$ \\
\hline & 7)社交場 & ティスコ・パーティー・学校・ホテル・キャンプ・レストラン \\
\hline & 8) 宗教 & 礼洋婸、神社、寺、塞圆 \\
\hline
\end{tabular}




\begin{tabular}{|c|c|c|}
\hline & 9)旅行 ·観光 & 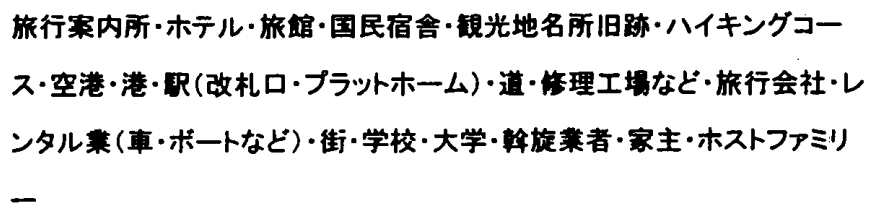 \\
\hline & 10）訪問先 & 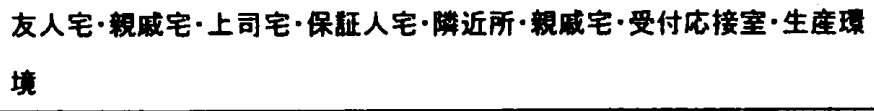 \\
\hline & 11）安全·保全 & 交番·雷察·病院 \\
\hline & 12）公共機関 & 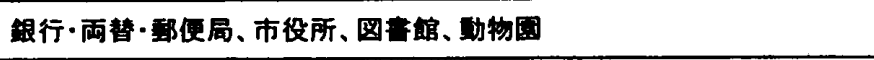 \\
\hline \multirow[t]{2}{*}{ (3) 数语 } & 1) 公的学校 & 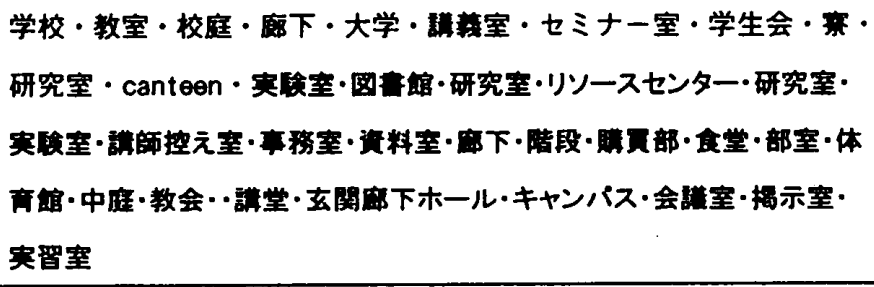 \\
\hline & 2)各種学校 & 自野莗学校·浯学学校 \\
\hline (4) & & 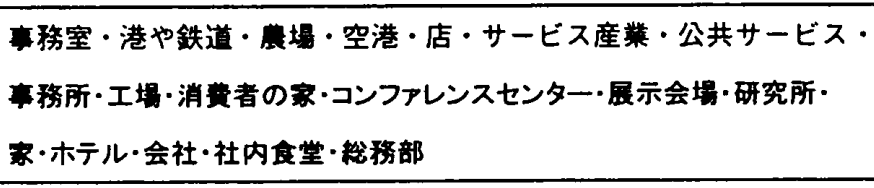 \\
\hline (5)メディフ & $\begin{array}{l}\text { 1) テレビ・ラジオ } \\
\text { 2) 雨話・电子メール・ } \\
\text { 手紙 }\end{array}$ & \\
\hline
\end{tabular}

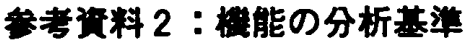

\begin{tabular}{|c|c|c|c|}
\hline $\begin{array}{l}\text { 機 } \\
\text { 能 }\end{array}$ & $\begin{array}{l}\text { 钼 } \\
\text { 念 }\end{array}$ & 1)梅報 & 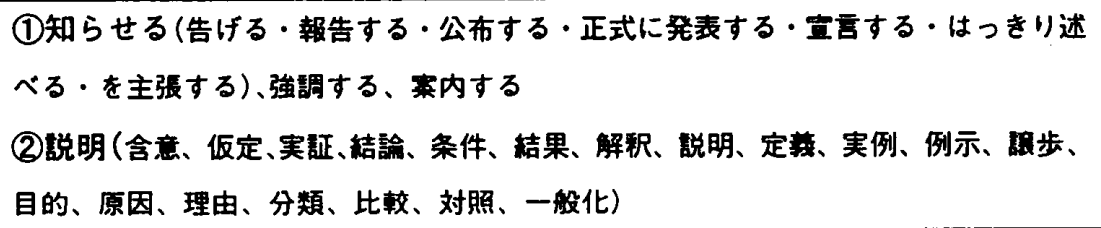 \\
\hline & & 2)自己表出 & 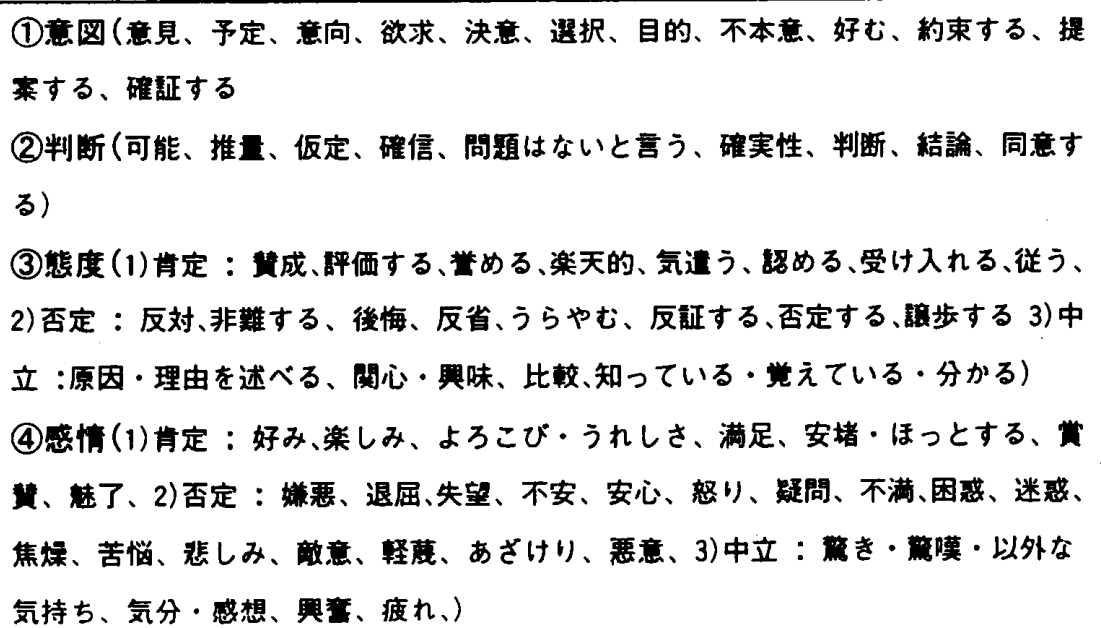 \\
\hline
\end{tabular}




\begin{tabular}{|c|c|c|}
\hline $\begin{array}{l}\text { 操 } \\
\text { 作 }\end{array}$ & 3)人間関係 & 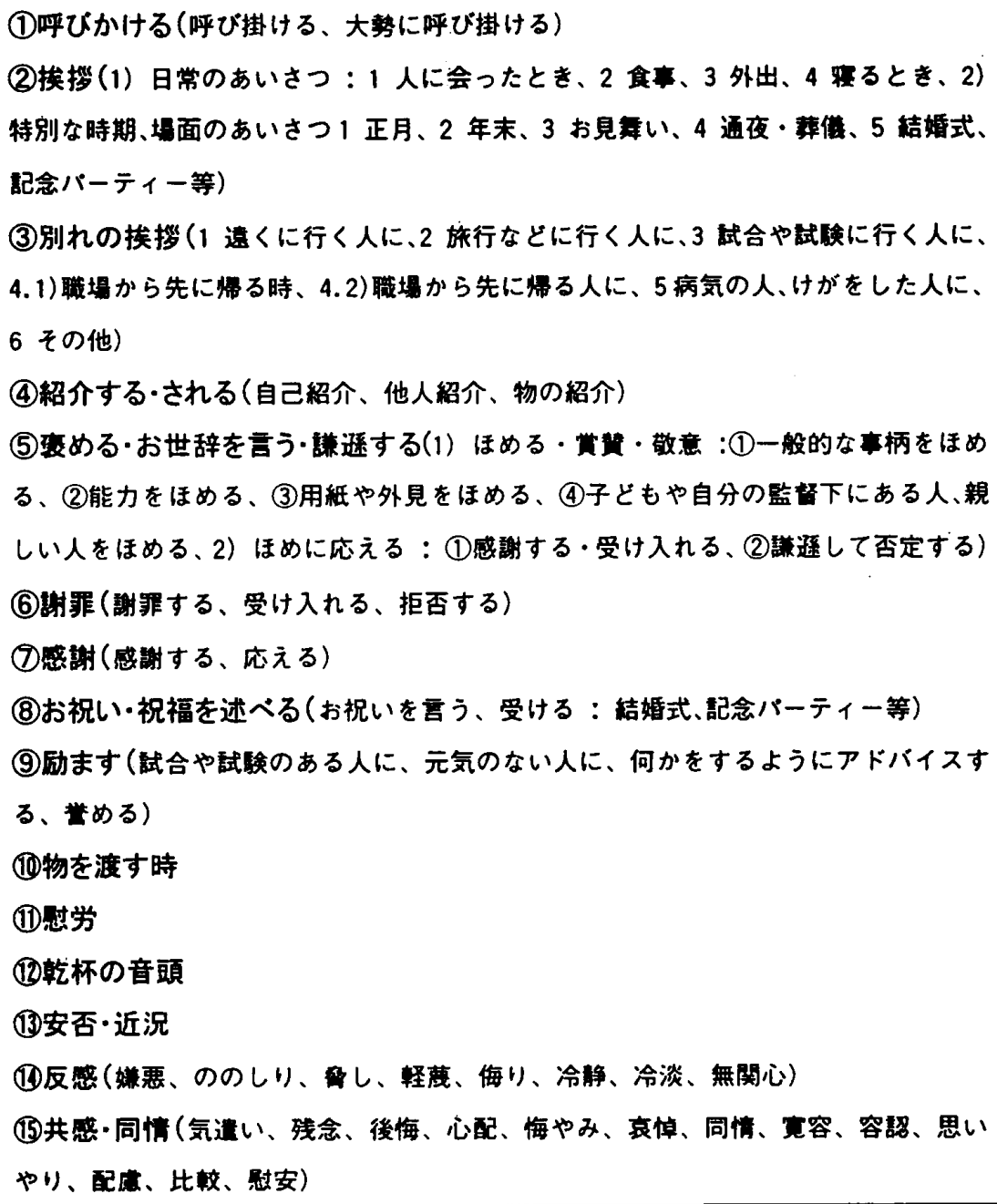 \\
\hline & 4)倒きかけ & 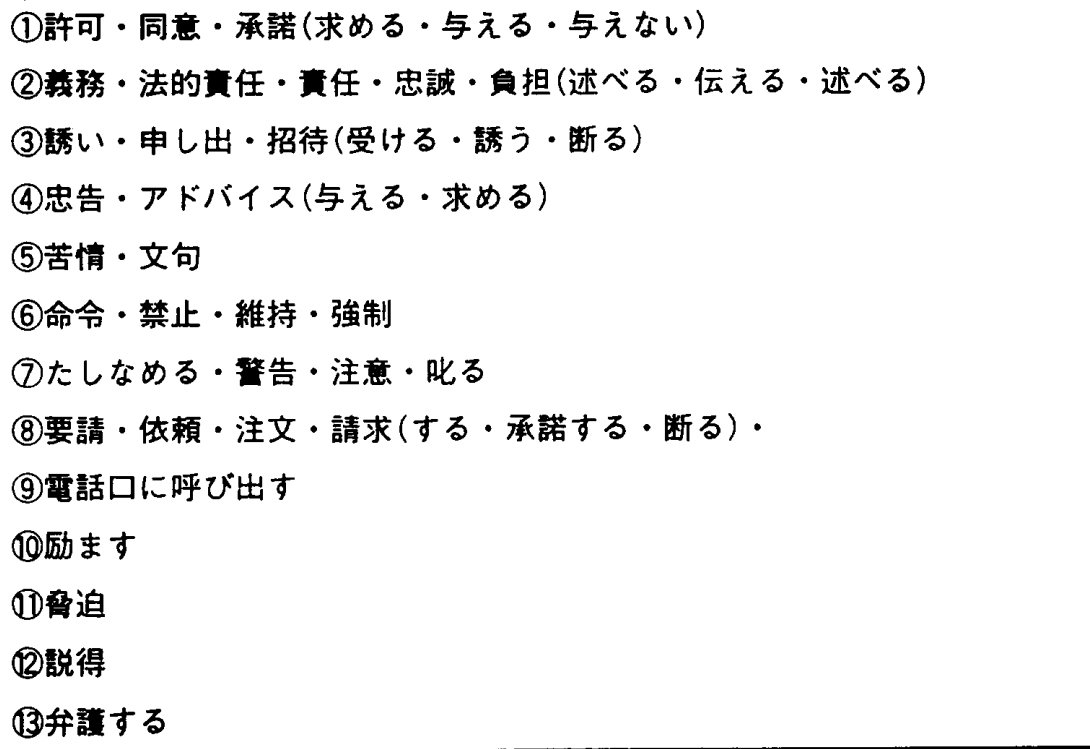 \\
\hline
\end{tabular}

考稘料 3：リスニングのテクスト・タイブの分析基华

(1)公衆アナウンス (駅構内・社内・デバートなどの放送) ・作業などの指示や命令

(2)スビーチ・諢義・プレゼンテーション・説教、 
(3)儀式(式・宗教的儀式)、

(4)エンターエンターティメント(ドラマ・ショー・読み物・歌・娛楽番組・ドキュメンタリー 番組)、

(5)スボーツ解説

(6)ニュース、

(7)公開ディベード・訸論（話し合い）

(8)対面対話と会話（雑談）

(9)電話の会話

(10就職の面接

(11)コマーシャル

注）日本語教育樴関におけるコース・デザインの方は項目が 17 もあったので、まとめられる ものはまとめて 12 項目にした。

(3)儀式(式・宗教的價式)や》公開ディベード・議論は日本語にはあまりないと思われる。また

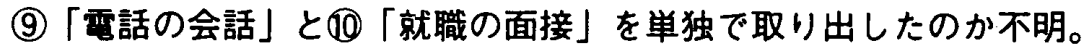

5）「コマーシャル」はともかく、10）「作業などの指示・命令」は機能なので、ここでは合わ ない。

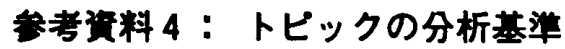

1)個人の確認、(自分の名前を言う·名前のつづりを言う・住所を言う・雷話番号を言う・生年月日と出 生地を言う・年龄・性を言う・既婚か未婚かを言う・国籍を言う・出身地や瞕莱を言う・家族を説明する・ 好き嫌いを言う・他人の特徵を言う・他人から情報を䦚き出したり理解する)

2) 家·地域·㻴境、(家やアパートそして部屋を説明する·家にあるもの(家具·客具·食器など)につい て話す・経费や施設について言う・地域と自然㿞境を説明する・他人から同様の説明を得て理解した り意見を交換する)

3）仕事（職坦での日常的な作菜を説明する・莱務に関することについて情報や意見を交換。他人から 同様の説明を得て理解したり意見を交换する)

4)自由時閒、㛝祭(いつ自由時間があり余眃に何をするかを話す・趣味や公共の娛楽そして個人の 娛菜、マスメディア、スポーツ、読書に関して話す・他人から同様の説明を得て理解したり意見を交換 し、娱楽施設を利用する)

5）旅行・交通（仕事や休撅のために道路、鉄道、海上、空路による交通手段を利用したり言及する)

6)時事(政治、経済、流行、政府や政府形㛑、犯罪や司法、戦争と平和、社会問題について他人と情 報や考えを交换する)

7)健康と身体的管理・育児、(元気である、空腹である、疲れたかどうかについて述べる・個人の快適 さについて話す・個人の街生に関することを言及し必要な品物を入手する·健康や病気について言及 して医師や歯科医にどこが恶いのか説明し、医㩧サービスや保険に言及し、このようなことについて 情報や考えを交换する)

8)教育(教育に関すること、特に教育の種類、学校の教科、资格に関して情報や考えを交換する)

9)而い物、(食料品、衣料品、家庭用品之喫煙者に必要な物を手に入れられる買い物施設を利用で き、価格を話し合い、蕒った品物の代金を支払う・こうした事柄について情報を交换し考えを述べる) 
10)食べ物と飲み物、(さまざまな種類の食料と饮み物に言及し、レストランや計食堂でも注文する・ 食べ物、飲み物、欲食できる場所について情報や考えを交换する)

11)サービス機関（郵便、雷話、電報、銀行、大(公)使馆、医療機関、車両嶅備機関、ガソリンスタン ドに言及し、それについて車ね、利用する)

12)埥所 (道や物の境所を承ねたり教えたりする)

13）天気、(天気予報を理解し、天候と天気の状態に関する情報を授受する）

14)他人との関係、(個人的関係に言及する·社交生活に参加する・文通を処理する)

15)家庭・家族関係

16）日本文化・習惯 